\title{
IMPACT OF REGULATORY DECISIONS OF THE REPUBLIC OF LATVIA ON SUSTAINABLE PRODUCT SUPPLY PROVIDED BY THE FOOD RETAIL CHAINS
}

\author{
Santa Bormane ${ }^{1}$, Daina ŠĶIltere ${ }^{2}$, Anda Batraga ${ }^{3}$ \\ University of Latvia (Latvia)
}

\begin{abstract}
This article reflects the impact of regulatory decisions of the Republic of Latvia on the food retail sector and sustainable product supply provided by food retail chains, as well as on operational trends. Attention has been drawn to the law of the Republic of Latvia on the key characteristics of foodstuffs and sales on the market. The research covers development of classification of the main instruments characterizing the products subject to the national regulation, as well as development of a scheme of the impact of the Latvian authorities on the operation of food retail chains. To implement the goal and tasks of the research, the authors have applied quantitative and qualitative research methods of economics, i.e., comparison, grouping, graphical, assessment and analytical methods. The research is based on the results of the previous research conducted by the authors so far, the law of the Republic of Latvia, scientific works published by other scientists, general and special literature and periodicals. The authors have summarized the findings and conducted comparative analysis of the regulatory decisions of the Republic of Latvia as well as presented a market survey within the research.

KEYWORDS: sustainability, sustainable development, sustainable product supply, integrated marketing communications for sustainability; integrated marketing communication instruments.
\end{abstract}

JEL CODES: M31, L66.

DOI:

\section{Introduction}

People living in today's world, can no longer think about today only, since decisions of the past and orientation towards satisfaction of the current needs have led to challenges in the environmental, social and economic areas. Following the usual pace and ignorance of the principles of sustainable development determining satisfaction of the residents' physiological, social and other needs in preserving the environment and eco-diversification can endanger the possibilities to satisfy the needs of future generations (Praude, Bormane, 2013: 165). Due to this reason, sustainable way of thinking is desirable and vital both in the context of the state, region or company development, and in such common everyday decisions of individuals as re-use of packaging, waste sorting, choice of food, etc.

The problem of research. Consumers lack information on the characteristics of the purchased products, for instance, such as composition and quality; they do not have knowledge on the nutritional value, packaging, raw materials, as well as their impact on human health and the environment, recycling possibilities, etc. The labelling of products may serve not only as a tool of integrated marketing communications

1 Santa Bormane - PhD student at the Faculty of Business, Management and Economics, University of Latvia, Latvia Scientific interests: sustainability, economic growth, marketing

E-mail: santa.bormane@gmail.com

Tel. +37126582423

2 Daina Škiltere - Dr., professor at the Faculty of Business, Management and Economics, University of Latvia, Latvia Scientific interests: sustainability, economic growth, marketing

3 Anda Batraga - Dr., assoc. professor at the Faculty of Business, Management and Economics, University of Latvia, Latvia Scientific interests: sustainability, economic growth, marketing 
in attracting consumers' attention and inciting a purchase, but also as a means that improves - through the information it carries - consumers' knowledge on a certain product, its nutritional value, use and utilisation.

The decisions and directives of the European Union, the Latvian national legislation, the Cabinet regulations and other legislative enactments are tools by which the state can alter the market relations among manufacturers, sellers and consumers seeking to provide consumers with accessible information that enhances their knowledge and affects the demand. As a result of various regulations, the product assortment in stores changes, thus reflecting relationships among the consumer, the manufacturer, the trader (retail chain), or the state.

Today, a nationwide economic, social and environmental problem is that consumers often lack information and knowledge about a product, because the label of it is just a visually attractive element successfully performing its function as a marketing tool that incites purchasing. However, the label often lacks information on the product characteristics that are crucial to consumers, e.g., such as nutritional value, ingredients, quality, etc. This is important information, which should be indicated not only in the interests of the producer or seller, but it also should serve the interests of consumers, however, this process is usually incomplete, and the information available on the packaging of a product is poor. The same problem relates to the packaging of a product, its raw materials, impact on human health, the environment, as well as on the options related to re-use of packaging and waste processing, etc.

The goal of this research is assessment and analysis of the regulatory decisions affecting the operation of food retail chains in Latvia which in turn affect product supply on the shop shelves. The authors have chosen the food retail chains in Latvia as the research object. The following tasks have been set as necessary for conducting the research:

- To investigate the regulatory decisions of the Republic of Latvia affecting the operation of food retail chains in Latvia.

- To analyse the operation trends of food retail chains in Latvia as far as product supply is concerned.

- To develop the main tools for characterization of products. To collect the main product-descriptive tools subject to the legislation of the European Union and Latvia.

- To study the product-descriptive tools used by food retail chains in integrated marketing communications oriented towards consumers.

To accomplish the goal and objectives of the research, the authors employed quantitative and qualitative research methods, i.e., comparative, grouping, graphical, evaluative, analytical research methods. The conducted analysis is based on the results of the authors' previous studies, the legislation of the Republic of Latvia, scientific papers, general and special literature, and periodicals. The authors have collected and analysed the regulatory decisions of the Republic of Latvia and conducted a comparative analysis and a market survey.

\section{Food as a precondition for sustainable and healthy life}

Food consumed on a daily basis is an integral part of our everyday lives. It gives us energy, provides proper functioning of the body, comfort and relish. Many people know the quotation of the French author Anthelme Brillat-Savarin: "Tell me what you eat, and I will tell you what you are" (Rangarajan, 2004: 42). This quotation reveals to the greatest extent the simple truth that food and nutrition is part of our life-style and philosophy of human life. The choice, quality, origin, diversity and nutritional value of products, as well as other significant parameters will reflect on human health sooner or later.

According to the authors, this fact might be easily proved by analysing data on life expectancy and a daily food basket. According to the statistical data of the World Health Organization on the average life expectancy at birth, the longest life expectancy was registered in Japan in 2015 accounting for 83.7 years, while the calculated average life expectancy in the rest of the world was 71.4 years in 2015 (World Health Statistics (WHO), 2016). Great contribution to this achievement has been put by the government of Japan, which issued a recommendatory food guide in 2005 containing information on balanced distribution and quantities of nutrients to be ingested on a daily basis in combination with regular physical activities and absorption of 
liquid (tea or water) (The Japanese Government's Official Advice on Food, 2016). Ten years later, National Centre for Global Health and Medicine in Tokyo conducted research to find out the impact of these recommendations on mortality rates and discovered that participants who closely followed the food guide had a 15 percent lower mortality rate (Gander, 2016). Summarizing these data, the authors would like to stress that the consumed food affects human health and, correspondingly, life expectancy. The question is what foodstuffs (origin, quality, ingredients, etc.) and where are available on the market.

At the same time, consumers frequently lack information and knowledge though the label of a product is visually attractive and encourages to purchase a product, i.e., frequently it does not contain sufficient information on the product characteristics crucial to consumers, such as nutritional value, labelling, etc. This is crucial information, which must be indicated in the interests of consumers, however, usually it is not provided completely, and the information on the packaging label of a product is rather poor. The same thing relates to the packaging and raw material of product, its impact on human health and the environment, recycling options, etc.

Information related to labelling and the label of a product, as well as other essential characteristics, is regulated by national laws, the Cabinet Regulations and other regulatory enactments. Thus, these are the national instruments applied, which are at the disposal of the state and make producers and traders to be obliged to and comply with. Information availability enhances the knowledge of consumers and affects the demand resulting in the change of product supply on the shop shelves. This is how the link between the consumer, the producer, the trader (a retail chain) and the state is reflected.

\section{Challenges to sustainable development in food retail companies}

It is wonderful, if an individual has sufficient resources and time to provide self-grown fruit, vegetables, berries and similar products, thus guaranteeing that these products are natural, organically grown and contain no chemical admixtures harmful to health. However, taking into account that an increasing share of the population prefers life in the cities (see Table 1) due to better opportunities for employment and ample provision for their family, the possibilities to maintain and cultivate their own garden are significantly limited, and there is only a handful of enthusiasts ready to contribute their time and effort. The majority opt to purchase ready products instead and use their free time for other activities.

Table 1. Share of permanent residents (\%) by their place of residence at the beginning of the year in cities and countryside of Latvia 2010-2016

\begin{tabular}{|l|r|r|}
\hline .Year & City & Countryside \\
\hline 2010 & $67.84 \%$ & $32.16 \%$ \\
\hline 2011 & $67.81 \%$ & $32.19 \%$ \\
\hline 2012 & $67.59 \%$ & $32.41 \%$ \\
\hline 2013 & $67.51 \%$ & $32.49 \%$ \\
\hline 2014 & $67.83 \%$ & $32.17 \%$ \\
\hline 2015 & $67.91 \%$ & $32.09 \%$ \\
\hline 2016 & $68.04 \%$ & $31.96 \%$ \\
\hline
\end{tabular}

Source: Statistical data form Central Statistical Bureau of Latvia (2016).

There are various options for food purchase. "Greenly thinking" individuals try to buy food directly from the producer (farmers, organic farms, etc.) and most often attend the market. There are farms representing themselves and offering self-grown products, but there are also traders-brokers, who sometimes are not informed on the actual origin of products, therefore buyers must be educated and able to assess the offer.

However, despite the offer of good quality products on the market, the majority of people in the developed countries buy food in retail shops, since these places are better accessible, and, for the purposes of time saving, 
many other daily products and goods are available in such shops also. Data on the fresh food sales indicators in the European Union (EU) shows that direct sales between farmers and consumers represent only $2 \%$ of the fresh food market. Food is mostly distributed through supermarkets, hypermarkets and discounters, which account for $54 \%$ of the total edible grocery sales in the EU (European Parliament, 2016: 5). At the same time, it should be taken into account that the rapid pace of today's life and continuous rush urges to use our time expediently, therefore people choose to purchase all or nearly all of the necessary food in the same place. The essential factor in favour of the retail chains in comparison, for example, with, the market, is availability of parking lots, various payment options (including debit card payments), flexible business hours, etc. Referring to the previously mentioned time saving and convenience, it should be noted that shopping centres occupied by food retail shops offer many other services necessary for daily use, for example, banking, dry-cleaning, repair of footwear and other services making consumers to choose these trading venues. In the opinion of the authors, this data and specific character of shopping centres prove that food retail companies are significant sources of food for the major part of society.

Due to the above-mentioned reason, the kind of products available on the shelves of food retail chains is very important in the context of the human health perspective. An increasing share of society pay attention to the quality of consumed food; however, there is still a large number of individuals not paying sufficient attention to the information on it. Usually the reasons are not related to people's wish to consume such products, but rather to the lack of knowledge on the impact of products' substances or ingredients on their health. In this regard, there is a number of product parameters revealing challenges and opportunities for the creation of sustainable supply of products.

According to the authors, one of the decisive factors in relation to the product supply on the shelves of food retail chains is the assortment of products, i.e., the proportion of products of local producers and organic products in relation to other products within the same product group. Arrangement of these organic and ecological products on the shelves is a different aspect. It is generally known that upon making a decision to purchase a product, buyers first of all assess the product located at the eye level. This specific character has been discovered and is used by producers and traders, therefore, it is often estimated that producers are ready for surcharge or special contractual conditions so that to place their products in the necessary place of the shelf.

The type of packaging also is important and affects the buyer's decision to buy or not to buy a particular product. For example, considering the fact that the shelf-life of organic and ecological products is usually shorter, since they use no artificial preservatives or other chemical substances that guarantee the delay of the product quality deterioration, it is essential to supply packaging of lower weight or volume. Thus, the buyer can use up a product in one go, and, upon a repeated purchase, buy a new and fresh product without concern about deterioration of quality of the previously bought product. However, the shelves of food retail chains in Latvia show a trend that products with comparatively short shelf-life, for example, dairy products, are not available to consumers in the late hours. This reason is related to the fact that, in accordance with the law of Latvia, retail chains themselves are responsible for the destruction of waste (i.e., products with expired shelflife), therefore, it should be concluded that shops do not want to undertake risk related to the excess of unsold products. However, such a situation has affected the supply of products with relatively short shelf-life.

The problem related to the disposal of food with expired shelf-life is actual not only to the end consumer, but also to the shops of food retail chains. Referring to the research conducted in 2016 by IVL Swedish Environmental Research Institute on Estimates of European food waste in EU-28 in 2012 (see Table 2), it is obvious that food wholesale and retail companies have wasted in total approximately 5 million tons of food in 2012. In the opinion of the authors, from a perspective of sustainable development of a food retail company, these unsold products are things that might have been converted into cash. In certain respect, foregone revenue is losses, furthermore, the company is obliged to pay additionally for sorting, storage and transfer of this waste processing. At the same time numbers reflecting the volume of yearly wasted food are alarming, taking into consideration the fact that there are many regions in the world, where people lack food and die of starvation.

Summarizing all the previously mentioned and listed, the authors want to stress that today food retail companies are significant places for food purchasing used by people due to time saving and convenience, therefore, the advised supply of products regulated by the law could improve public health, observance of the environmental protection requirements and economic benefits, thus providing complex promotion of sustainable development of a particular company, in this case - food retail chains. 
Table 2. Estimates of European food waste in EU-28 in 2012

\begin{tabular}{|l|l|l|}
\hline \multicolumn{1}{|c|}{ Sector } & Food waste (million tonnes) with 95\% CI* & Food waste (kg per person) with 95\% CI* \\
\hline Primary production & $9.1 \pm 1.5$ & $18 \pm 3$ \\
\hline Processing & $16.9 \pm 12.7$ & $33 \pm 25$ \\
\hline Wholesale and retail & $4.6 \pm 1.2$ & $9 \pm 2$ \\
\hline Food service & $10.5 \pm 1.5$ & $21 \pm 3$ \\
\hline Households & $46.5 \pm 4.4$ & $92 \pm 9$ \\
\hline Total food waste & $87.6 \pm 13.7$ & $173 \pm 27$ \\
\hline *Confidence interval & & \\
\hline
\end{tabular}

Source: IVL Swedish Environmental Research Institute (2016: 4).

3. Impact of the regulatory decisions of the Republic of Latvia on sustainable product supply provided by the food retail chains

In order to provide equal market conditions for all participants and, at the same time, protect interests of consumers, the state on its part has established several institutions and organizations dedicated to developing binding laws, rules and regulations and to following their control and observation. Figure 1 schematically depicts the state institutions, hierarchy and their impact on food retail chains in Latvia.

The Ministry of Economics of the Republic of Latvia is the leading state administrative institution in the field of economic policy formation in Latvia. The ministry develops and implements structural policy of national economy, internal market policy (for goods and services), entrepreneurship development policy, investment policy, consumer rights protection policy and other policies in the fields defined in the regulatory enactments (Ministry of Economics of the Republic of Latvia, About the Ministry). While, in relation to food retail-trade, the Ministry of Economics itself is more focused on the development and implementation of the trade and its regulation policy, as well as on development of draft laws regulating the sector, and development of planning documents (By-law of the Ministry of Economics, 2010), whereas other binding duties are delegated to other subordinated institutions:

- Investment and Development Agency of Latvia promotes competitiveness of Latvian companies by attracting foreign investments and helping to absorb the European Union (EU) funds (Investment and Development Agency of Latvia, Goals and Competences).

- Competition Council of the Republic of Latvia supervises the observance of the Advertising Law and prohibition against the abuse of dominant position and prohibited agreements by market participants (Competition Council of the Republic of Latvia, Goals. Tasks. Priorities).

- Consumer Rights Protection Centre supervises trade of goods and provision of services, as well as provides information necessary to consumers, and helps consumers in resolution of conflicts (Consumer Rights Protection Centre, About CRPC).

The Ministry of Agriculture of the Republic of Latvia is the leading state administrative institution in the sector of agriculture, forestry and fisheries (Ministry of Agriculture of Republic of Latvia, 2017). Several institutions with influence on the food retail sector are subordinated to the Ministry of Agriculture:

- Food and Veterinary Service provides control of food circulation in the entire territory of Latvia providing availability of safe and harmless food to consumers (Food and Veterinary Service).

- State Plant Protection Service supervises destruction of packaging of products.

- Scientific Institute of Food Safety, Animal Health and Environment "BIOR" provides food quality, safety, assessment of production technology and risks, as well as competitiveness of the companies involved in the food circulation (Scientific Institute of Food safety, Animal Health and Environment "BIOR"). 


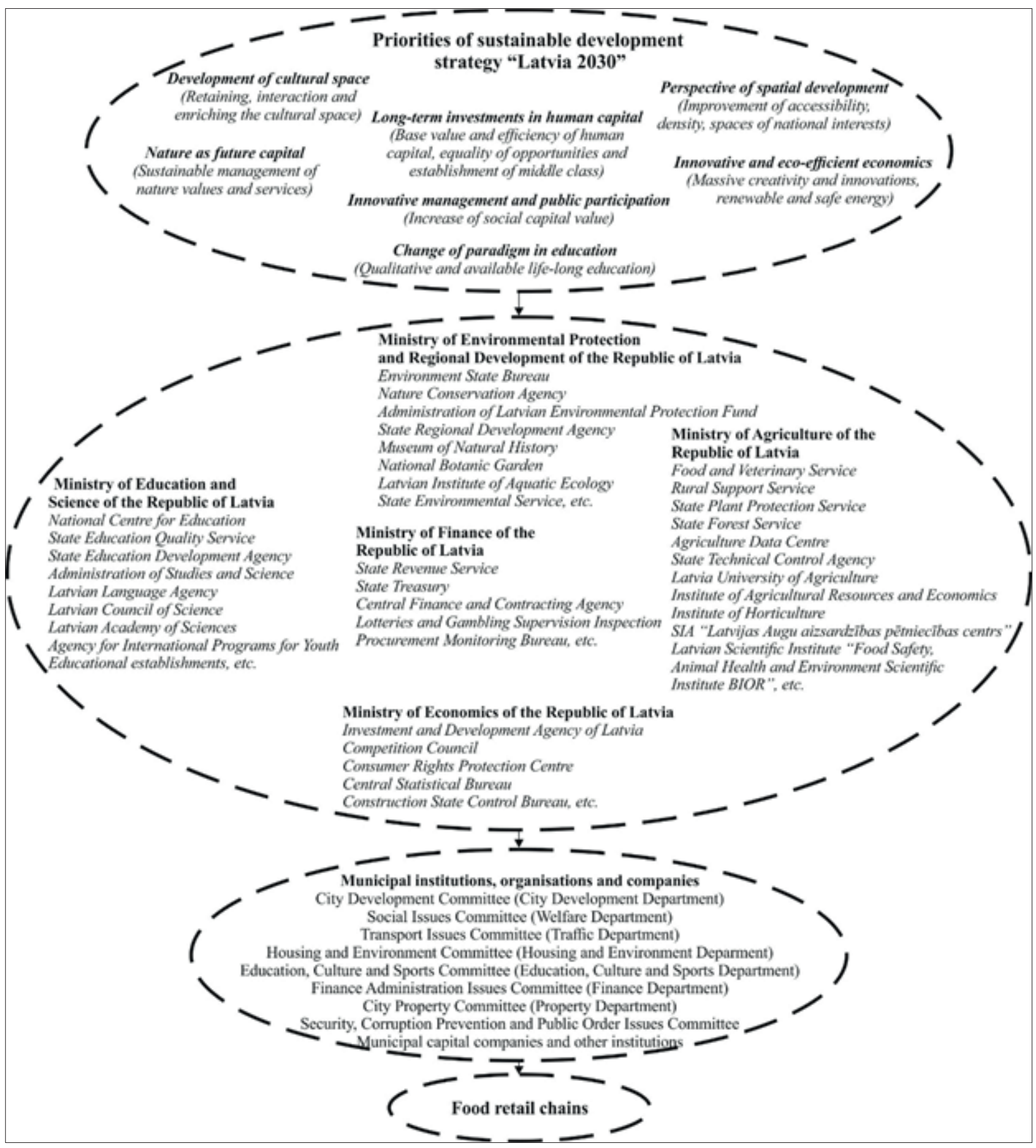

Fig. 1. State's impact on sustainable operations of food retail chains

Source: created by the authors.

Each of the listed public institutions and subordinated bodies is responsible for a certain supervision, regulatory or control function, however, at the same time, authority, rights and duties of these institutions are defined in particular laws and regulatory enactments regulating the food retail sector in Latvia.

Food and Veterinary Service (FVS) subordinated to the Ministry of Agriculture is one of the institutions related to control and supervision of food circulation to the largest extent. By-law of the Food and Veterinary 
Service (By-law of the Food and Veterinary Service, 2005) in combination with the Packaging Law (Packaging Law, 2002), Law on the Safety of Goods and Services (Law on the Safety of Goods and Services, 2004) and the Cabinet Regulations No. 808 Regarding Materials and Articles Intended to Come Into Contact With Food (Cabinet Regulations No. 808, 2012) regulate criteria regarding design of food packaging, information on application of product, protection against environmental impact, composition of packaging materials so that to avoid negative impact on the consumers' health and comply with hygiene requirements. In relation to product supply to a retail company, depending on the type of product packaging and materials used, appropriate storage conditions both in the warehouse and on the shop shelves must be provided to preserve the quality of a product.

Furthermore, Waste Management Law (Waste Management Law, 2010) and the Cabinet Regulations No. 184 Regarding Separate Waste Collection, Preparation for Re-use, Recycling and Material Recovery (Cabinet Regulations No. 184, 2013) regulate not only collection, management and processing of foodstuffs, but also affects the offered diversity of pre-packing of the same type product on the shelves of shops. For example, milk can be available to consumers in various packaging, i.e., PET bottles, polypacks, tetra-packs or, in separate cases, in glass tare. Each of these packaging types represents a different type of waste subject to different ways of storage and transfer for processing that the trader should provide, if the product is not used up.

Based on the By-law of the Food and Veterinary Service (By-law of the Food and Veterinary Service, 2005), Law On the Supervision of the Handling of Food (Law On the Supervision of the Handling of Food, 1998) and the Cabinet Regulations No. 545 Procedures for the Training of Persons Employed in Handling of Food in the Area of Food Hygiene (Cabinet Regulations No. 545, 2015), there is regulated observance of hygiene requirements and food traceability in all phases of food handling, operations of a self-control system within a company and supervision of food shelf-life. Referring to the supply of products, proportion of products, their packaging which determines special storage conditions (temperature, humidity and such), as well as proportion of products with short shelf-life, a trained supervision personnel is required within a developed system. All this may result in a situation, when, for example, such frequently used product as fresh milk with short shelf-life could not be available to consumers at the end of the day.

Food and Veterinary Service (FVS) (By-law of the Food and Veterinary Service, 2005) in cooperation with the State Plant Protection Service and the Scientific Institute of Food Safety, Animal Health and Environment "BIOR" (Law on Circulation of Genetically Modified Organisms, 2007) provides supervision and control of genetically modified food. By-law of the FVS (By-law of the Food and Veterinary Service, 2005), Law on Circulation of Genetically Modified Organisms (Law on Circulation of Genetically Modified Organisms, 2007) and the Cabinet Regulations No. 457 Regarding Deliberate Release of Genetically Modified Organisms (Cabinet Regulations No. 457, 2009) define the information with additional indication required regarding the impact of genetically modified organisms (GMO) on the environment, human health and principles, seeking to educate and inform society regarding the circulation of genetically modified organisms. Regarding product offer, proportion with long shelf-life is mainly affected, since GMO are created mainly to improve consistence against the environmental impact and longer preserve the physical and chemical properties or so-called quality. Following the consumer interests, these regulatory enactments define the labelling requirements for the products containing GMO, because a consumer, when purchasing a particular product must be informed about the composition of this product and its impact on health.

A number of regulatory enactments and decisions have been developed also in relation to organically grown food. Referring to the Law On Agriculture and Rural Development (Law on Agriculture and Rural Development, 2004) it has been provided for that the FVS is the main institution controlling organic farms subjects to the Cabinet Regulations No. 485 providing for the procedures of supervision and control of organic farming (Cabinet Regulations No. 485, 2009). As far as the organically grown and produced products are concerned, they are subjects to the Council Regulation (EC) No. 834/2007 on organic production and labelling of organic products (Council Regulation (EC) No. 834/2007, 2007) and the Council Regulation providing for detailed rules for organic production, labelling and control. It also provides that a product requires at least $95 \%$ of ingredients complying with the standards provided for in the Council Regulation (EC) No. 834/2007 to be considered "organic" (Commission Regulation (EC) No. 889/2008, 2008). 
In relation to labelling of products, the role of a regulator has been assigned to the Consumer Rights Protection Centre (CRPC) subordinated to the Ministry of Economics of the Republic of Latvia. The Consumer Rights Protection Law (Consumer Rights Protection Law, 1999), Cabinet Regulations No. 595 Regarding Requirements for the Provision of Information On Non-prepacked Food (Cabinet Regulations No. 595, 2015) and Cabinet Regulations No. 115 Regarding Requirements for the Labelling of Prepacked Food (Cabinet Regulations No. 115, 2015) define general product labelling principles regulating the standards on general labelling requirements, i.e., references to composition, nutritional value, origin, producer country, importer, weight, shelf-life, etc. These regulatory enactments provide the minimum amount of information to be indicated, which is necessary for the consumer upon purchasing goods.

Competition Council is also subordinated to the Ministry of Economics of the Republic of Latvia. In accordance with the Competition Law (Competition Law, 2002) and the Advertising Law (Advertising Law, 2000) this Council implements the state policy on the matters related to development and protection of competition. In cooperation with the CRPC, FVS, and Health Inspectorate and the National Electronic Mass Media Council (NEPLP) the observation of the Advertising Law is supervised. In accordance with the Competition Law (Competition Law, 2002), Unfair Retail Trade Practices Prohibition Law (Unfair Retail Trade Practices Prohibition Law, 2016) and Consumer Rights Protection Law (Consumer Rights Protection Law, 1999), the abuse of dominant position by market participants and protection of consumer interests is supervised. Regarding the product supply, the previously mentioned regulatory enactments are crucial, since they affect not only the end price of the product, but also the range of the offered products, as well as diversity within the same product group, i.e., the number of types of the same product on the same shelf. Taking into consideration the fact that usually advertisement is addressed to a wide circle of consumers, it is able to affect also such instruments characterizing the product as proportion of premium and economy class products and proportion of new product categories on the shelves of shops.

Regarding import foodstuffs and their characterizing parameters (packaging, labelling, composition, etc.), these are subjects to the above mentioned regulatory enactments, issued by the Republic of Latvia which are still in force. Considering the fact that import products are imported from foreign countries, regulatory enactments of the Republic of Latvia, in particular, the Official Language Law, provides for that every imported good the labelling, manual, guarantee documents or technical passport of which contains information in foreign language, must be accompanied by translation of such information into the official language (Official Language Law, 2000). Since the Republic of Latvia operates open economic system, import products, including foodstuffs, are not exposed to direct barriers for entry into the local market provided that all the requirements in relation to quality, packaging and labelling of products etc. specified in the regulatory enactments of the Republic of Latvia are complied with. In relation to import duty on import goods, Customs Law (Customs Law, 2016) is binding in the territory of the Republic of Latvia, however, taking into account the fact that free movement of goods is allowed within the borders of the EU, customs duties and tariffs mainly affect only the goods of non-EU origin (European Commission, 2014). In relation to the supply of products, entry of import products into the market affects the range of product assortment, product diversity in the same product group, proportion of new product categories, proportion of daily consumer products etc.

Taking into account the fact that a number of instruments characterizing the products are subjects to national law, regulatory enactments and control, authors have summarized the main characteristics of products (see Table 3).

Summing up, the authors conclude that a number of instruments characterizing the product are subjects to the regulation of public authorities and control of subordinated bodies, however, looking from the viewpoint of sustainable development, in the opinion of the authors, there is a space to take a step further. There is a possibility to include novelties in the current laws, Cabinet Regulations and other regulatory enactments in order to promote appearance of sustainable supply of products on the shelves of food retail shops.

So far, the authors have found out that the food consumed on daily basis affects human health to the largest extent, and thus - life expectancy, and that today food retail companies are significant places of food purchase. To provide equal conditions for all participants on the market and, at the same time, to protect consumer interests, food retail chains and product supply are subjects to many regulatory enactments in Latvia. 
Table 3. Main instruments characterizing the product subject to public regulation

\begin{tabular}{|c|l|}
\hline Item & \multicolumn{1}{|c|}{ Instruments characterizing the product } \\
\hline 1 & Range of the assortments of supplied products \\
\hline 2 & Diversity of the supplied products within the same product group \\
\hline 3 & Number of supplied types of the same product on the same shelf of the shop \\
\hline 4 & Diversity of pre-packing of the supplied products of the same type on the shelves of the shop \\
\hline 5 & Protective packaging \\
\hline 6 & Design and attraction of product packaging \\
\hline 7 & Product packaging with information on the use of product \\
\hline 8 & Attraction of labels of the supplied products \\
\hline 9 & $\begin{array}{l}\text { Arrangement of labels of the supplied products on the product without obscuring the original information } \\
\text { provided by the producer }\end{array}$ \\
\hline 10 & Information on product provided by labels of the supplied products \\
\hline 11 & Information on product ingredients provided by labelling of the supplied products \\
\hline 12 & $\begin{array}{l}\text { Information on origin, producer country, importer, weight, shelf-life, etc. of the product provided by } \\
\text { labelling of the supplied products }\end{array}$ \\
\hline 13 & Proportion of the supplied products labelled with barcodes \\
\hline 14 & Large proportion of the supplied products with short shelf-life \\
\hline 15 & Large proportion of the supplied products with long shelf-life \\
\hline 16 & Proportion of new product categories \\
\hline 17 & Proportion of premium class products \\
\hline 18 & Proportion of economy class products \\
\hline 19 & Proportion of daily consumer products (bread, milk, meat etc.) \\
\hline 20 & Proportion of alcoholic products \\
\hline 21 & Proportion of household products, including household chemicals \\
\hline
\end{tabular}

Source: created by the authors.

Due to these reasons and seeking to promote the use of sustainable integrated marketing communications within companies, including the ones aiming at product supply, the authors have commenced voluminous research, in the course of which managing specialists of food retail chains of Latvia were asked to assess a number of criteria and the reasons affecting sustainable development of these companies and their applied marketing strategy. Within this research, the authors intended to find out and summarize specialists' opinions on the current situation in the food retail sector in Latvia. The aim was to identify problems and provide recommendations for the application of integrated marketing communications promoting sustainable development of companies, preservation of the environment, improvement of the society welfare level and the overall national economic growth.

Taking into consideration that the authors carried out the analysis of the regulatory decisions of the Republic of Latvia seeking to find out their impact on the food retail sector, one of the tasks of the sector was to find out and discover the operational trends of food retail chains and to determine why opinions and attitude among the market participants are so different.

As the authors have observed before, FVS is one of the main institutions in Latvia related to control of food circulation to the largest extent. In relation to the supervision of observation of various regulations and rules provided by the FVS, attitude of the retail chains is ambiguous, since part of the chains considers that national law poorly promotes company's operation, while the other part considers the promotion of operation as sufficient.

It is interesting that attitude of market participants to standards and directives related to indications on nutritional value and health of the products, in accordance with the EU regulations on provision of information on foodstuffs to the consumers, to indications on nutritional value and healthiness on foodstuffs etc. is different, part of them considers that standards and directives related to indications on nutritional value and health of the products, in accordance with the EU regulations and Latvian law on provision of information on foodstuffs to the consumers do not promote company's operation, while the other part considers the opposite. 
Furthermore, opinions, attitude and trends are also radically different in relation to regulation of import products, supply of import products which is also affected by the customs tariffs and taxes. Moreover, attitudes differ on sales of organic products and their compliance with quality standards, inclusion in the shop supply and on other matters. Thus, there is a reason for further wide research, and the results of it on the trends of sustainable development of food retail chains in Latvia will be published in the nearest future.

Summarising, the authors conclude that the goal of the regulatory decisions of the Latvian authorities is both to provide equal conditions for all participants on the market and, at the same time, to protect consumer interests. However, food retail chains could not be the only entities contributing to sustainable development of Latvia. Public and municipal support to locally produced products so that to promote operations of companies, rules of certification, additional requirements for quality compliance (e.g., for organic products) and tax rates on food, as well as other promotional instruments could also serve as grounds for national economic growth, preservation of the environment and improvement of the welfare level of society.

\section{Conclusions}

Today, food retail/trade companies are significant places used by people to purchase food seeking to save time and for convenience. Therefore, the advised supply of products regulated by the law could improve public health, observance of the environmental protection requirements and economic benefits, thus providing complex promotion for sustainable development of particular companies, in this case - food retail chains.

The food consumed daily affects human health to the largest extent, and thus life expectancy, therefore, today food retail companies are significant places of food purchase. To provide equal conditions for all participants on the market and, at the same time, to protect consumer interests, food retail chains and product supply are subjects to regulation by a number of regulatory enactments of Latvia.

A number of instruments characterizing the product are subjects to the regulations by public authorities and control of subordinated bodies. From the point of view of sustainable development, inclusion of novelties in the laws, the Cabinet Regulations and other regulatory enactments, makes the state capable not only to promote sustainable supply of products on the shelves of food retail shops, but also to stimulate consumer competence by improving information level. Thus, correspondingly, the state can promote changes in the demand for ecological, environment-friendly good quality products.

While communicating with consumers, food retail companies have possibilities to direct and promote trade of ecological products based on the national law and regulatory enactments and to emphasize the instruments characterizing the products.

The goal of the regulatory decisions of the Latvian authorities is both to provide equal conditions for all market participants and to protect consumer interests at the same time, however, food retail chains should not be the only entities contributing to sustainable development of Latvia. Public and municipal support to locally produced products promoting operations of companies, rules of certification, additional requirements for quality compliance (e.g., for organic products) and tax rates on food, and other promotional instruments could also serve as grounds for the national economic growth, preservation of the environment and improvement of the welfare level of society.

\section{References}

About CRPC. Consumer Rights Protection Centre. Available at: http://www.ptac.gov.lv/en/content/about-crpc Advertising Law. (2000). Parliament: Official Gazette. Available at: https://likumi.lv/ta/id/163-reklamas-likums By-law of the Food and Veterinary Service. (2005). Cabinet Regulations, No. 142. Available at: https://likumi.lv/doc. php?id=102419

By-law of the Ministry of Economics. (2010). Cabinet Regulations, No. 271. Available at: https://likumi.lv/doc. php?id=207119

Competition Council. (2017). Goal. Tasks. Priorities. Available at: http://www.kp.gov.lv/lv/par-konkurences-padomi/ merkis-uzdevumi-strategija

Competition Law. (2002). Parliament: Official Gazette. Available at: https://likumi.lv/ta/id/54890-konkurences-likums 
Consumer Rights Protection Law. (1999). Parliament: Official Gazette. Available at: https://likumi.lv/doc.php?id=23309 Council Regulation on Organic Production and Labelling of Organic Products, Council Regulation (EC) No. 834/2007. (2007). European Commission. Available at: http://eur-lex.europa.eu/legal-content/LV/TXT/ PDF/?uri=CELEX:02007R0834-20130701\& from=LV

Council Regulation on Organic Production and Labelling, and Control of Organic Products Commission Regulation (EC) No. 889/2008. (2008). European Commission. Available at: http://eur-lex.europa.eu/legal-content/LV/TXT/ PDF/?uri=CELEX:02008R0889-20150101\&from=LV

Customs Law. (2016). Parliament: Official Gazette. Available at: https://likumi.lv/ta/id/283024

Gander, K. (2016). Japan's High Life Expectancy Linked to Diet, Study Finds. Independent. Available at: http://www. independent.co.uk/life-style/health-and-families/health-news/high-life-expectancy-in-japan-partly-down-to-dietcarbohydrates-vegetables-fruit-fish-meat-a6956011.html

Insight into the European Union policy. Customs. (2014). European Commission: Communication Directorate General, Population Information Service.

IVL Swedish Environmental Research Institute. (2016). Estimates of European Food Waste Levels.

Law On Agriculture and Rural Development. (2004). Parliament: Official Gazette. Available at: https://likumi.lv/doc. php?id=87480

Law on Circulation of Genetically Modified Organisms. (2007). Parliament: Official Gazette. Available at: https:// likumi.lv/doc.php?id=167400\&mode=DOC

Law on the Safety of Goods and Services. (2004). Parliament: Official Gazette. Available at: https://likumi.lv/doc. php?id $=87664$

Law on the Supervision of the Handling of Food. (1998). Parliament: Official Gazette. Available at: https://likumi.lv/ doc.php?id=47184

Ministry of Agriculture (2017). About the Ministry. Available at: https://www.zm.gov.lv/zemkopibas-ministrija/statiskas-lapas/par-ministriju?nid=278\#jump

Ministry of Agriculture. (2017). About the Service. Available at: http://www.zm.gov.lv/partikas-un-veterinaraisdienests/statiskas-lapas/par-dienestu?nid=2061\#jump

Ministry of Economics of the Republic of Latvia (2017). About Ministry. Available at: https://em.gov.lv/lv/par_ministriju/

Packaging Law. (2002). Parliament: Official Gazette. Available at: https://likumi.lv/doc.php?id=57207

Praude, V., Bormane, S. (2013). Sustainable Marketing - Prospects and Challenges under Present Economy. Journal of Social Sciences of Klaipeda University, No. 3 (11), p. 165-176.

Procedure for the Supervision and Control of Organic Farming (2009). Cabinet Regulations, No. 485. Available at: https://likumi.lv/doc.php?id=193115

Procedures for the Training of Persons Employed in Handling of Food in the Area of Food Hygiene. (2015). Cabinet Regulations, No. 545. Available at: https://likumi.lv/ta/id/276821-partikas-aprite-nodarbinato-personu-apmacibaskartiba-partikas-higienas-joma

Rangarajan, D. V. (2004). Sura's Quotable Quotes, Adages and Sayings. Chennai: Sura Books.

Regarding Requirements for the Provision of Information on Non-Prepacked Food. (2015). Cabinet Regulations, No. 595. Available at: https://likumi.lv/ta/id/277278-prasibas-informacijas-sniegsanai-par-nefasetu-partiku

Regulations Regarding Deliberate Release of Genetically Modified Organisms. (2009). Cabinet Regulations, No. 457. Available at: https://likumi.lv/doc.php?id=192625

Regulations Regarding Materials and Articles Intended to Come into Contact with Food. (2012). Cabinet Regulations, No. 808. Available at: https://likumi.lv/doc.php?id=238306

Regulations Regarding Requirements for the Labelling of Prepacked Food. (2015). Cabinet Regulations, No. 115. Available at: https://likumi.lv/ta/id/272619-prasibas-fasetas-partikas-markejumam

Regulations Regarding Separate Waste Collection, Preparation for Re-use, Recycling and Material Recovery. (2013). Cabinet Regulations, No. 184. Available at: https://likumi.lv/ta/id/256092-noteikumi-par-atkritumu-dalitu-savaksanu-sagatavosanu-atkartotai-izmantosanai-parstradi-un-materialu-regeneraciju

Scientific institute BIOR. (2017). About us. Available at: http://www.bior.gov.lv/lv/top-menu/par-mums

Short Food Supply Chains and Local Food Systems in the EU. (2016). European Parliament: European Parliamentary Research Service.

Statistical Data from Central Statistical Bureau of Latvia. (2017). Available at: www.csb.gov.lv

The Japanese Government's Official Advice on Food. (2016). British Medical Journal (BMJ). Available at: http://www. independent.co.uk/life-style/health-and-families/health-news/high-life-expectancy-in-japan-partly-down-to-dietcarbohydrates-vegetables-fruit-fish-meat-a6956011.html

Waste Management Law (2010). Parliament: Official Gazette. Available at: https://likumi.lv/doc.php?id=221378

World Health Statistics (WHO). (2016). Life Expectancy at Birth in 2015. Available at: http://gamapserver.who.int/gho/ interactive_charts/mbd/life_expectancy/atlas.html 


\title{
LATVIJOS RESPUBLIKOS REGULIAVIMO SPRENDIMU POVEIKIS MAISTO PRODUKTU MAŽMENINÉS PREKYBOS G R A N D I N E I
}

\author{
Santa Bormane, Daina Šķiltere, Anda Batraga \\ Latvijos universitetas (Latvija) \\ Santrauka
}

Straipsnyje analizuojamas poveikis maisto produktų mažmeninei prekybos grandinei darnumo aspektu. Analizuojami Latvijos Respublikos įstatymo pokyčiai, tiesiogiai veikiantys maisto produktų prekybą rinkoje. Nustatyti esminiai maisto produktu pardavimo rinkoje reguliavimo instrumentai, realiai veikiantys maisto produktų prekybos tiekimo grandinę. Autoriai, siekdami tyrimo tikslo, taikė tiek kokybinius, tiek kiekybinius ekonomikos mokslo tyrimo metodus, tokius kaip palyginimas, grupavimas, grafiniai, vertinimo ir analitiniai. Pateikè tyrimo rezultatus, remdamiesi Latvijos Respublikos įstatymais, mokslinių straipsnių analize, kitų autorių specialia ir periodine literatūra analizuojamu klausimu.

Latvijos Vyriausybės priimtas įstatymas sudarè vienodas sąlygas maisto produktų rinkos dalyviams, kartu suvienodino prekybos plètros sąlygas ir taip apsaugojo vartotojų interesus. Šis įstatymas, ịtraukiantis darnumo elementus, sudaro galimybes ị rinką patekti ne tik kokybiškesniems maisto produktams, bet ir skatina vartotojus suvokti, kas yra darnumas. Tikètina, kad tai paskatins ekologiškų, aplinkai draugiškų geros kokybės produktų vartojimą. İstatymas sukurtas, remiantis nacionaline darnumo strategija Latvija-2030, čia ipareigotos penkios Latvijos ministerijos: Švietimo ir mokslo, Ekonomikos, Finansų, Aplinkos apsaugos ir regionų vystymo bei Žemès ūkio. Konstatuota, kad maisto mažmeninès prekybos tinklai neturètų būti vieninteliai subjektai, Latvijoje prisidedantys prie darnaus vystymosi. Pastebima, kad savivaldybių parama (naujos maisto produktų sertifikavimo taisyklès, papildomi kokybės reikalavimai, mokesčiu sistema) vietinès maisto produkcijos gamintojams padeda vystyti nacionalinę ekonomiką ir užtikrina visuomenès gerovę.

PAGRINDINIAI ŽODŽIAI: darnumas, darnus vystymasis, darnus produktu tiekimas, rinkodaros komunikacija, siekiant darnumo, integruotos rinkodaros komunikacijos instrumentai.

JEL KLASIFIKACIJA: M31, L66.

Received: 2017.10.30

Revised: 2017.12 .30

Accepted: 2018.01.31 